\title{
Untying the knots of thinking: Wittgenstein and the role of philosophy in Christian faith
}

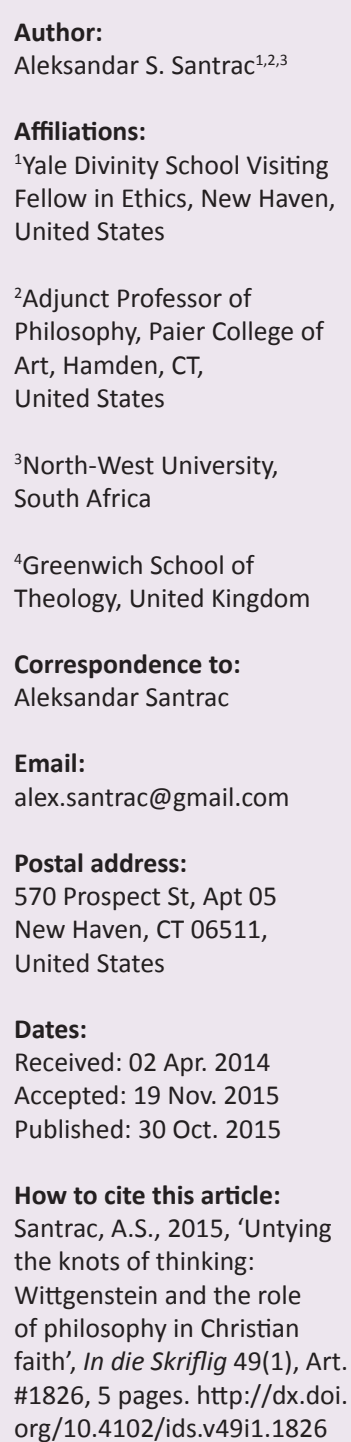

Read online:

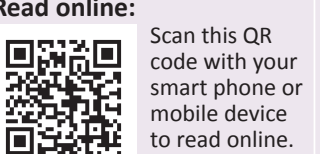

This article deals with Ludwig Wittgenstein's philosophy and how it can be properly applied in Christian theology. It provides useful tools for methodology in Christian thinking. According to Wittgenstein, philosophy deals primarily with critical examination, clarification and evaluation of the language we use. Wittgenstein's ideas - including the concept of mystery beyond linguistic forms, the idea of language game and its possible evolution, the impossibility of the ultimate truth and the concrete application of language - have the potential to play a very significant methodological role in every form of theological doctrinal expression.

Wittgenstein en die rol van die filosofie in die Christelike geloof. Hierdie artikel handel oor Ludwig Wittgenstein se filosofie en hoe dit behoorlik toegepas kan word in die Christelike teologie. Ditbied nuttige gereedskap vir metodologie in Christelike denke. Volgens Wittgenstein, handel filosofie hoofsaaklik oor die kritiese ondersoek, verduideliking en evaluering van die taal wat ons gebruik. Wittgenstein se idees - insluitend die konsep van misterie buite taalkundige vorms, die idee van taalspel en die moontlike evolusie, die onmoontlikheid van die uiteindelike waarheid en die konkrete toepassing van taal - het die potensiaal om ' $n$ baie belangrike metodologiese rol te speel in elke vorm teologiese leerstellige uitdrukking.

\section{Introduction}

Within the context of the Church's education and practice, the question of teaching or using philosophy has become relevant from the very beginnings of its history. What was the purpose of philosophy in the origin and development of Christian theology? Can we find the appropriate ancient or contemporary philosophical model by which we can clearly articulate the purpose of philosophy and then utilise this purpose and/or methodology in (communicating) Christian faith and theology? Some of the purposes, concepts and methodological tools of Ludwig Wittgenstein's philosophy may contribute substantially to better understanding and clarification of theological ideas.

Firstly, a few remarks about the use of philosophy by the primitive Christians. The majority of the Church Fathers would probably support the observation of some contemporary Christian philosophers, ${ }^{1}$ who assert that Colossians 2:8 is just making a comparison between deceptive philosophy based on worldly wisdom, and philosophy based on Christ (Geisler \& Feinberg 2001:73). Therefore, philosophy as a discipline should not be discarded altogether and Christian philosophy (philosophia Christi) does indeed have its legitimate place. For the Church Fathers, however, biblical or Christ-centred philosophy was regarded as a higher discipline than all the 'pagan philosophies'. In Christian thinking, biblical philosophy, based on Christ and exceptional moral life, was always contrasted with false worldly or pagan philosophy. Apart from Christ, philosophy was foolishness. Regarding its content, therefore, a Christian biblical and holistic philosophy of life took precedence over unbiblical philosophies. Indeed, as Tertullian exclaimed: 'What has Athens to do with Jerusalem? Or the Academy with the Church?' ${ }^{2}$

1.The project of the Church Fathers coincides with the project of contemporary Christian philosophers, namely, to promote Christian philosophy as counterpart to different 'worldly' or 'pagan' philosophies and worldviews (either Greco-Roman philosophy then or contemporary atheistic and humanistic philosophies today).

2.'What indeed has Athens to do with Jerusalem? What concord is there between the Academy and the Church? What between heretics and Christians? Our instruction comes from "the porch of Solomon", who had himself taught that "the Lord should be sought in simplicity of heart". Away with all attempts to produce a mottled Christianity of Stoic, Platonic, and dialectic composition! We want no curious disputation after possessing Christ Jesus, no inquisition after enjoying the gospel! With our faith, we desire no further belief' (Tertullian n.d.:ch. 7).

Note: This article is based on the same methodology and research previously published by the author on his personal web page www. aleksandarsantrac.info, 'Untying the Knots of Thinking: Wittgenstein and the Role of Philosophy' in Adventism Society of Adventist Philosophers, Conference: Teaching Philosophy: Promise or Peril? San Francisco, Nov 17-18, 2011, Aleksandar S. Santrac, DPhil, ThD (cand) Associate Professor of Philosophy.

Copyright: (C) 2015. The Authors. Licensee: AOSIS OpenJournals. This work is licensed under the Creative Commons Attribution License. 
According to the traditional and/or scriptural Christian worldview, there is no doubt that even if we use the expression 'biblical philosophy' for the purpose of discourse or contextualisation, it does not mean that this philosophy is one of many. It is the superior form of knowledge, because biblical knowledge is the only one that leads to eternal salvation. As (White 1897:1) stated: 'The Christian believer possesses the key to true philosophy. ${ }^{3}$ Concerning the content, therefore, there is an incompatibility and incongruity between biblical Christian philosophy and pagan philosophies.

Consequently, teaching and utilising philosophy in Christian religious institutions has become daunting and challenging. Christian tradition, nevertheless, was never afraid of pursuing philosophical studies (or any other studies), but pursued them only as the 'knowledge of the world' (the possibility of natural theology) contrasted with and assessed by the 'knowledge of Christ' (the theology of grace). In regard to philosophy, the Church has demonstrated both permissive and prohibitive attitudes (De Wulf 1911). Regarding the material body of knowledge, The role of philosophy in Christian circles is not very promising, because the Church leans toward fideism, thus denying the values of Thomistic and rational Protestant Calvinistic traditions. 'Seeds of pagan knowledge' are properly and sporadically used, but the Christian worldview itself (with its ontological and epistemological assumptions) is rightly measured only by the standards of the Scriptures.

However, the challenge of teaching philosophy in Christianity is not just the difficult evaluation of the content of 'pagan philosophy'. It is also a methodological challenge. Christians in general should not just study philosophy as a material body of knowledge, but should use it as a tool for religious, theological and biblical studies. Every student in an 'Introduction to Philosophy' class might know what the abbreviation CASE means. This is a fourfold use of philosophical methodology or tools in pursuing theological and religious studies, according to Geisler and Feinberg (2001:73):

1. Clarification (thinking clearly).

2. Argumentation (thinking correctly).

3. Systematisation (thinking comprehensively).

4. Examination (thinking critically).

Argumentation (the use of basic logic) and systematisation (the use of comprehensive and systematic presentations of the worldview) are widely accepted in Christian theology. On the other hand, clarification (the use of clear or clarified concepts and ideas) and examination (the use of critical forms of thinking) are somehow undermined and even disallowed within some Christian institutional thinking. There is a constant need in Christian circles to make theological things clear and to critically assess existing doctrinal expressions. Concerning the specific methodological role, especially in 3.In several instances this article endeavors to show that Christian faith and
contemporary worldviews, like postmodernism and post-postmodernism, are mutually exclusive 'philosophies' (Santrac 2007; 2008b). clarification and examination, the philosophy of Ludwig Wittgenstein (1889-1951) is useful in developing Christian philosophical discussion.

\section{Wittgenstein and elucidation/language game}

The scope of this article will not permit an investigation into the details of Ludwig Wittgenstein's life that moulded his way of thinking (see Monk 1991). This article will, however, try to use the well-known expressions in his works Tractatus Logico-Philosophicus (TLP) and Philosophical Investigations (PI) to demonstrate the importance of clarification and examination in general, and specifically the value of these philosophical tools for Christian education. This article will not deal with details of the evolutionary development of Wittgenstein's ideas, concepts and phrases from TLP to PI. The specificity and uniqueness of Wittgenstein's thought patterns will serve the purpose of this article. Interestingly, though Wittgenstein is sometimes portrayed as a postmodern philosopher, his philosophy rejects scepticism and affirms foundationalism, namely the basic and proper certainty of human knowledge (for further controversial discussion, see Richter 2001). For Christians, this certainty (though beyond language) about reality and knowledge represents the appeal of his philosophy.

What is the basic logic of Wittgenstein's thought pattern? According to Wittgenstein, all philosophy is a 'critique of language' (TLP, 4.0031). His philosophy is analytical because it does not describe the specific object of philosophical thinking (e.g. traditional Being) but the language itself. He claims (TLP, 6.13): 'Logic or [structure of language] is not a theory but a reflection of the world. Logic is transcendental.' Logic represents a 'mysterious' pattern of the world expressed by language, because the world itself is mysterious. According to Wittgenstein, the world does not need the supernatural revelation of God in order to be mysterious (TLP, 6.4.3.2): 'How the world is, is completely indifferent for what is higher. God does not reveal himself in the world'. 'Not how the world is, is the mystical, but that it is' (TLP, 6.44). In addition, Stephen Mulhall from Oxford University even thinks that Wittgenstein's philosophy of religion was fideistic without specific criteria of rationality (Mulhall 2011:314). Mulhall has come to this conclusion because it seems evident that Wittgenstein does not trust in the traditional use of reason, but opens new vistas for the mystical use of language and mystical experiences beyond language.

This article will circumvent Wittgenstein's interpretation of objects of the world as facts/symbols/pictures (later games), and his presentation of the complex relationship between the world and language. It will extract only the thoughts that are essential for the purpose of this article. Wittgenstein says:

The object of philosophy is the logical clarification of thoughts. Philosophy is not a theory but an activity. A philosophical work consists essentially of elucidations. The result of philosophy is not a number of 'philosophical propositions', but to make propositions clear. Philosophy should make clear and delimit 
sharply the thoughts which otherwise are, as it were, opaque and blurred. (TLP, 4.112)

Therefore, Wittgenstein says that philosophy is the primary tool of clarification of the process of thinking. In contemporary terms (Kenny 2010:802): 'Philosophy does not discover any new truths, and philosophical problems are solved not by the acquisition of new information, but by the rearrangement of what we already know. ${ }^{4}$ Philosophy is, therefore, new perception and arrangement of ideas and concepts that will clarify the processes of thought. It is 'untying the knots of thinking', says Wittgenstein, and he concludes that ' $[e]$ verything that can be thought at all can be thought clearly' (TLP, 4.116). There are things, however, about which we cannot even say anything. In that sense, as Wittgenstein said at the end of his Tractatus (TLP, 7): 'Wovon man nicht sprechen kann, darüber muß man schweigen' ['Whereof one cannot speak, thereof one must be silent']. Once we climb the ladder of understanding and make proper use of linguistic forms, we cannot grasp what 'mystical realities' are beyond the limits of language (see Zemach 1964).

In his PI, Wittgenstein reformulated some of his ideas from TLP by introducing the famous concept of the language game. This concept will be extremely useful when investigating the purpose of philosophy in Christian faith, as this article will demonstrate later. First of all, we need to understand that the key definition of the language game, according to Wittgenstein (PI, 7), is 'the whole, consisting of language and the actions into which it is woven'. So 'the language game' is not merely a speech or a discourse. To imagine a language means to imagine a form of life (PI, 19). Our words are woven into our activity and the 'forms of life' that may evolve. Wittgenstein explains:

There are countless kinds: countless different kinds of use of what we call 'symbols', 'words', 'sentences'. And this multiplicity is not something fixed, given once for all; but new types of language, new language games, as we may say, come into existence, and others become obsolete and get forgotten (PI, 23).

Language games, therefore, become unpredictable, and what is even more important is that they have separate rules, and may have little to do with one another (PI, 1.65). This means that objective certainty does not exist, and no proposition is limited to a single meaning, because every meaning is dependent on its context (Grenz 1995a:114). 'Ultimate truth' is bound within the limits/contexts of one's language or 'language game'.

The most well-known sentence in PI is (PI, 38): 'Philosophical problems arise when language goes on holiday.' This means that if language is taken out of context and philosophised

\footnotetext{
4.This reminds me of my daughters' room. Normally, they are never satisfied with the old toys, and they always crave for some new exciting dollies. Very often, in my 'Wittgensteinian' inclination, I explain to them that if they arrange the already my 'Wittgensteinian' inclination, I explain to them that if they arrange the already
existing dolls in a different manner, they will have 'new' toys and even 'new' games, without spending dad's money.
}

about it becomes confusing. Lois Shawver's illustration ${ }^{5}$ is useful in this context. Some concepts or ideas of the specific language game, therefore, may lose their grounding in concrete examples and proper usage or meaning in the course of time, especially if we 'philosophise' too much about them.

Here is a summation of this brief presentation of Wittgenstein's philosophy:

1. Philosophy is a methodological tool for criticism and clarification of language and thinking.

2. There are limits to this process because there is nothing understandable beyond the limits of language (the world remains a mystery).

3. We are all bound by our 'cultural form of life' or 'language game' that can evolve and be transformed.

4. Ultimate truth is an impossibility.

5. Some concepts or ideas within the 'language game' lose proper meaning if they are not tied to a concrete example or application.

This study will now venture to apply these five remarks in the discussion of the methodological role of philosophy in Christian theology and education.

\section{Clarification/examination of Christian thinking}

Firstly, our theological and/or educational philosophy should have a primary role in the clarification of existing concepts. Apart from the traditional distinction of content of revelation vs. content of rational thinking, we need to employ the tool of philosophy for elucidation - in explaining clear theological thinking. Thomas Aquinas (n.d.) explains the role of philosophy in dogmatics:

But sacred doctrine makes use even of human reason, not, indeed, to prove faith (for thereby the merit of faith would come to an end), but to make clear other things that are put forward in this doctrine.

Philosophy, therefore, is indispensable for the clarification of theological statements. The tool of reason will make doctrinal statements clear, lucid and sound.

Secondly, speaking about limits of language and mystery, this 'contemporary metaphysical' term is affirmed and proclaimed in the post-postmodern world. Beyond postmodernism lie religious phenomena: the mysterious revelation of the power and the nature of God. Commenting on the post-rational nature of evangelical theology, Stanley J. Grenz (1995b) claims:

Our theology must give place to the concept of 'mystery' - not as an irrational aspect alongside the rational, but as a reminder of the fundamentally non-rational or supra-rational reality of God. (p. 99)

5. It reminds me of a time when I was a child that I said "butterfly" over and over. Isn't it strange, I thought that we say "butter-fly" as though butter were to fly away, or "butstrange, I thought, that we say "butter-fly" as though butter were to fly away, or "buter-fly" and by the time that I had said this 15 times or so, the word no longer seemed to mean "butterfly" in the simple way it had. Often when one philosophizes about a concept the concept has "gone on holiday". We have lost our grounding in concrete examples. We know very well how to use the word "virtue" in a sentence, for example, but when we scratch our heads and wonder what "virtue" really means, then the word "virtue" is on holiday. We are just thinking about the word, not using it in the natura way that our language allows us to use it' (Shawver 1998:Commentary on PI, 38). 
There are ideas in theology that call for ultimate silence and awe. Beyond theological language lies the unknown the mystery of God. Onto-theology, in its comparison with analytic theology, involves theorising about God in a way that presupposes that reason is a reliable tool for arriving at clear knowledge of God, so that reasoning about God can ultimately remove divine mystery (Rae 2011:9).

With the existing language of the Scriptures, sometimes we think we can rationally grasp everything that is exegetically processed. However, the 'mystery of Christ' defies reason, both in content and interpretation, moving beyond existing rules of language and system.

Thirdly, bound by our 'cultural form of life' or 'language game' that can evolve and be changed, we certainly affirm the reality of the palette of 'Christian cultures': ultra-conservative, conservative, mainstream, liberal, progressive, and so on. Whatever culture we have in mind, we are bound by the language we use. However, Wittgenstein calls for the 'evolution' of the language game. It means we should strive towards the ultimate and most perfect unified language game, that is God's language game. Hermeneutically speaking, even biblical language games are bound within the limits of various traditions of interpretation. However, if we do believe in the transcendent Creator revealed in the immanency of the Redeemer, we have to think transcendentally about biblical hermeneutics and find the universal principles of the supernatural revelation of God. Let us strive towards the theological hermeneutics of the 'language game of universalisation', in the process of the evolution of the language game and cultural form of life. Contextualisation may be another example of 'language game evolution', and it is done in the New Testament writings. Gnostic terms that the apostle Paul used are one example. Perhaps we should 'translate' the 'language game of Christ' into the language game of worldly philosophy.

Fourthly, ultimate truth, just as impossibility, belongs to typical postmodern ideas. Since we are bound with our language game, we cannot know the ultimate truth. Owing to this postmodern hollowness, moving back to premodern or post-postmodern ideas about truth as mystery and dynamic suprarational power of God, namely Christ, might be relevant here. Let us also be reminded that Christ is the wisdom of God. Simon Critchley (2001) argues that the original aim of philosophy was not theoretical knowledge (as he thinks it is today), but rather wisdom. Philosophy, he says, was an 'eminently practical activity', but it has now been relegated to the role of 'an under-laborer to science, whose job is to clear away the rubbish that lies in the way to knowledge and scientific progress' (Critchley 2001:24, 1, 5). Christ is our philosophy as wisdom and our power above reason, the touchstone of the knowledge of the ultimate reality.

Finally, Wittgenstein noticed that concepts or ideas within a language game lose their proper meaning if they are not tied to a concrete example or application. If we wish to find a proper example in Christian thinking, we might opt for the most comprehensive concept of the conflict between Christ and Satan. In researching the problem of evil, the idea of great conflict (a biblical language game) might be useful if it is applied it to the situation of personal horrendous suffering, for example (Santrac 2008a:79-99). Any generic theodicy might have the problem of impropriety in real life situations, because we have no evidence of God's personal love towards those who go through horrendous forms of suffering. Compared to other theodicies, the great conflict theory is radical. Nevertheless, even with this biblical perspective on the problem of evil, we might have grave impediments in applying the belief in the everyday reality of radical suffering. It means we may need to redefine some ideas in order not to lose proper or original meaning. Sometimes we contemplate the Great Conflict concept so much that it 'goes on holiday'. It loses its primordial spiritual mystery and power in the face of intense personal anguish. Think less, live more. The same might be applied to philosophical and theological definitions of the Trinity in the face of the conventional liturgical prayer life based on communion with the Trinity.

\section{Conclusion}

In conclusion, philosophy as a tool should be very beneficial for Christian academia and for the application of systems of beliefs. The content of Greek philosophical heritage is mostly irreconcilable with the content of the Judeo-Christian biblical worldview. Indeed, only the Christian believer possesses the key to true philosophy' (White 1897:1). Unlike pagan philosophers, the Christian philosopher has the key of the knowledge of Christ and his redemptive work in the hearts of human beings. However, the Christian believer/ theologian/philosopher really needs an additional key, that is, the correct employment of philosophy as a creative human endeavour for the benefit of self-understanding and the understanding of reality. This application of philosophy as a tool has a purpose in the identification, clarification and critical examination of the dynamic 'language game' of a superior revelation of God. Philosophy, therefore, has great promise for every Christian institution, not only as ancilla theologiae, but also as a valuable apparatus in untying the knots of thinking.

\section{Acknowledgements Competing interests}

The author declares that he has no financial or personal relationship(s) that may have inappropriately influenced him in writing this article.

\section{References}

Aquinas, T. n.d., 'Article 8: Whether sacred doctrine is a matter of argument?', in New Advent, viewed 05 February 2015, from http://www.newadvent.org/ summa/1001.htm\#article8

Critchley, S., 2001, Continental philosophy: A very short introduction, University Press, Oxford. http://dx.doi.org/10.1093/actrade/9780192853592.001.0001

De Wulf, M., 1911, 'Philosophy', in The Catholic Encyclopedia, Robert Appleton Company, New York, viewed 12 December 2014, from http://www.newadvent. org/cathen/12025c.htm 
Geisler, N.L. \& Feinberg, P.D., 2001, Introduction to philosophy: A Christian perspective, Baker Books, Grand Rapids, Ml.

Grenz, S.J., 1995a, A primer on postmodernism, Eerdmans, Grand Rapids, MI.

Grenz, S.J., 1995b, 'Star Trek and the next generation: Postmodernity and the future of evangelical theology', in D.S. Dockery (ed.), The challenge of postmodernism An evangelical engagement, pp. 89-103, Victor, Wheaton, IL.

Kenny, A., 2010, A new history of Western philosophy - In four parts, Oxford Press, New York.

Monk, R., 1991, Ludwig Wittgenstein: Duty of genius, Penguin Books, New York.

Mulhall, S., 2011, 'Wittgenstein on faith, rationality and the passions', Modern Theology 27(2), 313-324. http://dx.doi.org/10.1111/j.1468-0025.2010.01678.x

Rae, M.C., 2011, 'Introduction', in O.D. Crisp \& M.C. Rea (eds.), Essays on Analytic Theology, pp. 1-30, Oxford University Press, Oxford.

Richter, D., 2001, 'Wittgensteinian foundationalism', Erkenntnis 55(3), 349-358. http://dx.doi.org/10.1023/A:1013363424636

Santrac, A.S., 2007, 'Reaching the postmodern mind', in Ministry, viewed 12 December 2014, from http://www.ministrymagazine.org/archive/2007/September/reachingthe-postmodern-mind.html
Santrac, A.S., 2008a, An evaluation of Alvin Plantinga's free will defense: Whether our power to do bad is something wrong, Edwin Mellen Press, New York.

Santrac, A.S., 2008b, 'Understanding and relating to the new world view', in Ministry, viewed 12 December 2014, from http://www.ministrymagazine. org/archive/2008/June/understanding-and-relating-to-the-new-worldview.html

Shawver, L., 1998, Commentary on Wittgenstein's philosophical investigations, viewed 12 December 2014, from http://users.rcn.com/rathbone/lwtocc.htm

Tertullian n.d., 'De Praescriptione Haereticorum', in The Tertullian Project, viewed 12 December 2014, from http://www.tertullian.org/works/de_praescriptione_ haereticorum.htm

White, E., 1897, 'The true light', Signs of the Times, January 28.

Wittgenstein, L., 1922, Tractatus Logico-Philosophicus, viewed 12 December 2014 from http://www.kfs.org/jonathan/witt/tlph.html

Wittgenstein, L., 1958, Philosophical Investigations, viewed 12 December 2014, from http://users.rcn.com/rathbone/lwtocc.htm

Zemach, E., 1964, 'Wittgenstein's philosophy of the mystical', Review of Metaphysics 18(1), 38-57. 